\title{
All stakeholders matter in faculty development
}

\author{
Citation for published version (APA):
}

Iqbal, Z. (2020). All stakeholders matter in faculty development: designing entrustable professional activities for small group facilitation. [Doctoral Thesis, Maastricht University]. Ipskamp Printing BV. https://doi.org/10.26481/dis.20201215mi

Document status and date:

Published: 01/01/2020

DOI:

10.26481/dis.20201215mi

Document Version:

Publisher's PDF, also known as Version of record

\section{Please check the document version of this publication:}

- A submitted manuscript is the version of the article upon submission and before peer-review. There can be important differences between the submitted version and the official published version of record.

People interested in the research are advised to contact the author for the final version of the publication, or visit the DOI to the publisher's website.

- The final author version and the galley proof are versions of the publication after peer review.

- The final published version features the final layout of the paper including the volume, issue and page numbers.

Link to publication

\footnotetext{
General rights rights.

- You may freely distribute the URL identifying the publication in the public portal. please follow below link for the End User Agreement:

www.umlib.nl/taverne-license

Take down policy

If you believe that this document breaches copyright please contact us at:

repository@maastrichtuniversity.nl

providing details and we will investigate your claim.
}

Copyright and moral rights for the publications made accessible in the public portal are retained by the authors and/or other copyright owners and it is a condition of accessing publications that users recognise and abide by the legal requirements associated with these

- Users may download and print one copy of any publication from the public portal for the purpose of private study or research.

- You may not further distribute the material or use it for any profit-making activity or commercial gain

If the publication is distributed under the terms of Article $25 \mathrm{fa}$ of the Dutch Copyright Act, indicated by the "Taverne" license above, 
This dissertation describes five studies conducted to develop and validate an EPA framework that could be used for professionalization of small group facilitators. In the General Introduction (Chapter 1), we describe faculty development and its contemporary challenges. Then, after describing EPAs and their characteristic features, we rationalize the potential suitability of EPAs to overcome the challenges in faculty development. Followed by highlighting the literature gap, we explain why there is a need to design an EPA framework for training and entrustment of small group facilitators. We then argue involving all stakeholders in the design process instead of developing the framework through conventional methods. Lastly, we explain why designing a framework might not be enough and why EPAs might need to be complemented with an instructional design model to systematically structure faculty development programs.

In order to develop and validate a comprehensive EPA framework for small group facilitation, five studies were conducted. These studies were guided by the following five research questions:

1. What are the current practices of utilizing EPAs in teacher training programs and how can EPAs be adopted more meaningfully in faculty development? (Study 1 - Chapter 2)

2. What are the EPAs for training and entrusting small group facilitators, according to teachers and students? (Study 2 - Chapter 3)

3. How do teachers and students involved in co-creating a faculty development program perceive their involvement and how do they reflect upon their co-creation experiences? (Study 3 - Chapter 4 )

4. According to expert educationalists, how valid is the earlier co-created EPA framework designed for small group facilitators? (Study 4 - Chapter 5)

5. How can the EPAs be complemented with an instructional design model to design and develop a training program? (Study 5 - Chapter 6)

In Study 1, described in Chapter 2, a literature review was conducted to explore and report the utilization of EPAs in the context of faculty development. The results showed that the use of EPAs for teacher training is a novel approach. Only a couple of programs were found in which EPAs for health professional educators and clinical teachers were designed and implemented. For several reasons, the existing frameworks were found unsuitable for other teaching roles, and there was a call to develop EPAs for training and entrustment of small group facilitators.

To fill this literature gap, a co-creation approach was used to develop an EPA framework for small group facilitation. In Study 2, discussed in Chapter 3, both students and teachers collaborated to design the framework, and three workshops were conducted to achieve the study objectives. In the orientation workshop, the participants were trained on the content, study design, and their expected roles. Then, a design workshop was conducted in which students and teachers enlisted 11 EPAs and 17 competencies of small group facilitators. Finally, in the consensus workshop, an agreement was achieved on 9 tasks and 12 competencies, followed by a mapping between the agreed upon EPAs and competencies.

Since co-creating an EPA was a novel approach, it was important to explore how the 
participating students and teachers perceive their co-creation experiences because their negative perceptions could jeopardize the sustainability of both the co-creation approach and the resulting framework. Therefore, in Study 3, described in Chapter 4, we interviewed 11 students and 11 teachers who co-created the framework in Study 2. The interviewees mostly reported a positive and productive co-creation experience. Students frequently reported that they felt comfortable during the co-creation exercise because of the supportive, friendly, non-confrontational, and motivating attitudes of the teachers within their groups. Similarly, the teachers shared that they were comfortable with the students' presence because of the respectful and co-operative attitudes of students shown during the activity. Some negative experiences were also reported, such as: teacher dominance, student shyness, lack of grip on study topic, and reluctant participation which limited the active contribution of the participants. The inclusion of both students and teachers in co-creating the framework was perceived essential as it offers multiple benefits for stakeholders, faculty development programs, and the co-creation process. With respect to the suggestions for improving student-teacher partnership, the most frequently mentioned recommendations were careful selection of the participants and their contextual training prior to the co-creation activity. The study concluded that engaging relevant stakeholders in the design process nurtures diversity and rigor, and therefore their inclusion as co-creators should be ensured in future educational initiatives.

Although a robust design approach was used to develop the framework, expert health professions educationalists were not consulted, which is important to ensure scrutiny and quality. Therefore, in Study 4, described in Chapter 5, we used the modified Delphi technique to validate the framework through international experts. Thirty-one health professions educationalists participated in three online rounds. In Round 1, a validated seven-item rubric was used to evaluate the quality of the pre-designed nine EPAs, which resulted in retention of three EPAs: namely, preparing for a small group session, facilitating a small group session and reflecting upon self and the session. In Round 2, participants selected nine competencies required to perform each agreed-upon EPA from the pool of 12 competencies. In Round 3, five, six, and four sub-activities achieved consensus for EPA 1, EPA 2, and EPA 3, respectively. The final framework also provided a detailed description of each EPA, including its context, specifications, entrustment resources and an entrustment scale.

The validated EPA framework elaborates the training content and outcomes that faculty development programs should aim to achieve. However, the framework does not provide details on the instructional design of an EPA-based faculty development program. In Study 5, described in Chapter 6, we proposed a task-based training model by complementing EPAs with the 4C/ID model. In this model, we explored the possibility of sequencing the training for an EPA into different learning tasks of variable complexities, followed by task-based training from simple tasks in a low fidelity simulated learning environment to complex tasks in the real workplace learning environment. We then proposed that the training must start from simple learning tasks in a low fidelity learning environment and with growing competence, the complexities of both 
the learning tasks and the learning environments should gradually be increased. Additionally, a longitudinal supervision should be provided across the training continuum in order to develop mutual trust and trainee-supervisor relationship, and to grant a well-informed entrustment decision.

Chapter 7 provides an overarching discussion about findings of the studies along with their theoretical and practical implications. The strengths and limitations of the whole project have also been discussed in addition to multiple recommendations for future researchers. Overall, this project provides a comprehensive EPA framework that could be used to train and entrust the teachers in their role as small-group facilitators. The participation of all three stakeholders students, teachers and expert educationalists - in the development and validation process highlights the strength of the resulting framework. The framework intends to hold multiple potential utilities for trainee teachers, program developers, educational leaders and students. This project also expands the literature on co-creation by adding the faculty development domain to it. We learned that including students and teachers in co-creating a framework for teacher training is an essential and timely educational advancement. Moreover, the project proposes complementing EPAs with 4C/ID where EPAs would define the training outcomes and 4C/ID would orchestrate the instructional design of the training program. We anticipate that this thesis might help in streamlining the professionalization of small group facilitators in health professions education. 


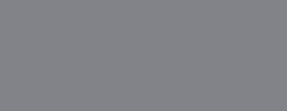

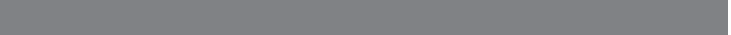
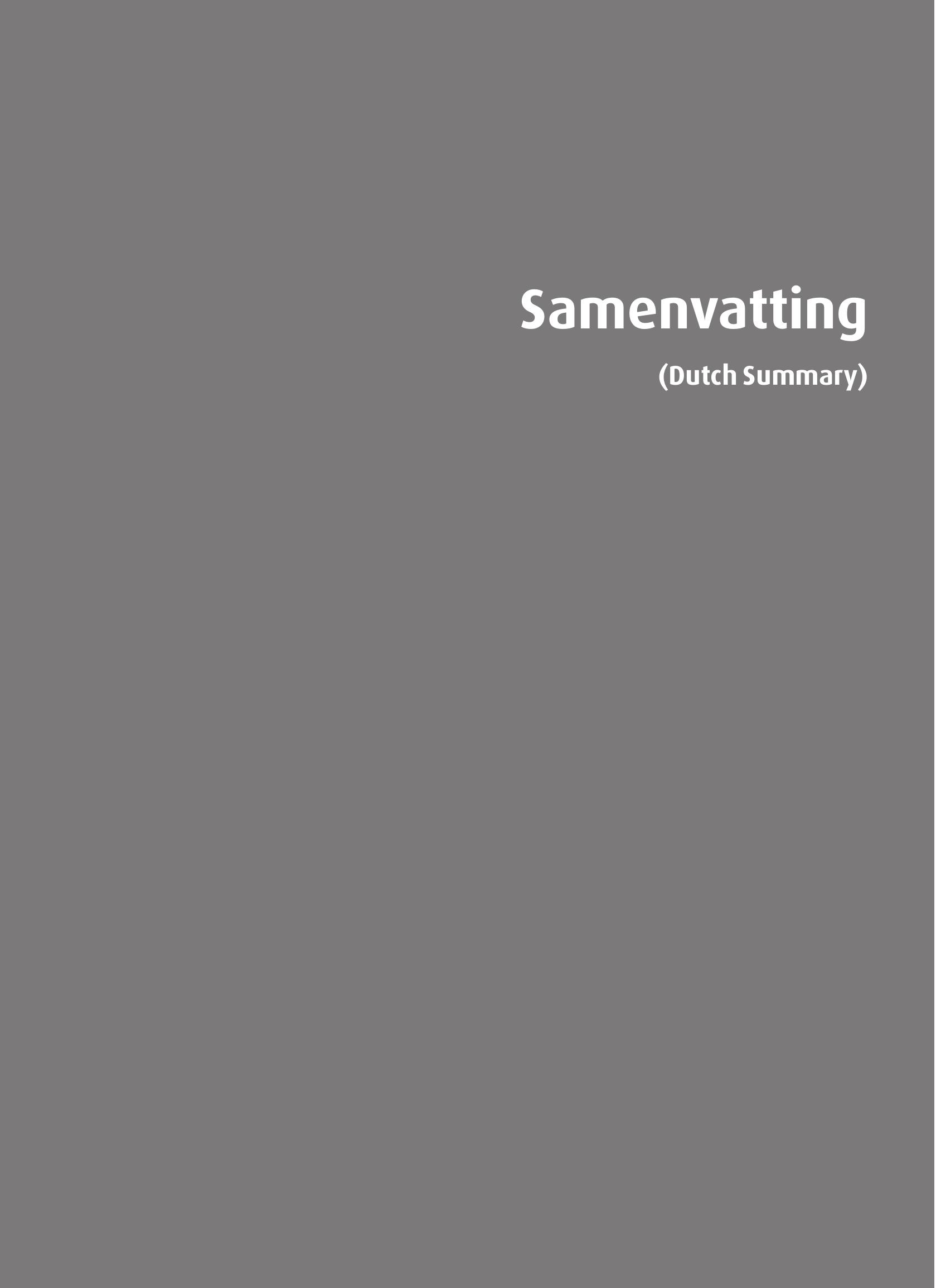
Dit proefschrift beschrijft vijf onderzoeken die ten doel hadden een kader voor Entrustable Professional Activities (EPAs), oftewel gestructureerde beschrijvingen van afgebakende professionele activiteiten, te ontwikkelen en te valideren dat kan worden gebruikt voor de professionalisering van begeleiders van kleine groepen. In de Algemene Introductie (Hoofdstuk 1) beschrijven we docentprofessionalisering en haar hedendaagse uitdagingen. Vervolgens, na het beschrijven van EPAs en hun kenmerkende eigenschappen, gaan we in op de vraag in hoeverre EPAs geschikt zijn om de bestaande uitdagingen op het gebied van docentprofessionalisering het hoofd te bieden. Na gewezen te hebben op de lacunes in de literatuur, lichtten we nader toe waarom het noodzakelijk is een EPA-kader voor het opleiden van en toevertrouwen van professionele activiteiten aan begeleiders van kleine groepen te ontwerpen. Vervolgens poneren we dat alle belanghebbenden betrokken moeten worden in dit ontwerpproces in plaats van het kader met behulp van conventionele methoden te ontwikkelen. Tot slot leggen we uit waarom het ontwerpen van een kader misschien niet volstaat en waarom EPAs mogelijk aangevuld dienen te worden met een onderwijsontwerpmodel dat de docentprofessionaliseringsprogramma’s systematisch vormgeeft.

Teneinde een sluitend EPA-kader voor de begeleiding van kleine groepen te ontwikkelen en te valideren, verrichtten we vijf onderzoeken. In deze onderzoeken waren de volgende vijf onderzoeksvragen leidend:

1. Wat is de huidige gang van zaken omtrent het gebruik van EPAs bij docentenopleidingen en hoe kunnen EPAs zinvoller worden ingezet bij docentprofessionalisering? (Onderzoek 1 Hoofdstuk 2);

2. Welke EPAs horen er volgens docenten en studenten bij het opleiden van en toevertrouwen van professionele activiteiten aan begeleiders van kleine groepen? (Onderzoek 2 - Hoofdstuk 3);

3. Hoe ervaren docenten en studenten gemoeid met het gezamenlijk ontwerpen of "cocreëren" van een docentprofessionaliseringsprogramma hun betrokkenheid en hoe reflecteren zij op hun ervaringen met cocreatie? (Onderzoek 3 - Hoofdstuk 4);

4. Hoe valide is volgens onderwijsdeskundigen het EPA-kader

dat eerder door middel van cocreatie werd ontworpen voor begeleiders van kleine groepen? (Onderzoek 4 - Hoofdstuk 5);

5. Hoe kunnen de EPAs worden aangevuld met een onderwijsontwerpmodel op basis waarvan een opleiding kan worden ontworpen en ontwikkeld? (Onderzoek 5 - Hoofdstuk 6).

In het eerste onderzoek dat wordt beschreven in Hoofdstuk 2, verrichtten we een literatuuronderzoek om inzicht te verkrijgen in het gebruik van EPAs in de context van docentprofessionalisering en dit vast te leggen. De resultaten lieten zien dat het gebruik van EPAs bij het opleiden van docenten een nieuwe aanpak is. We vonden slechts enkele programma's waarbij EPAs voor opleiders in de gezondheidszorg en klinisch docenten werden ontworpen en ingevoerd. De bestaande kaders werden om diverse redenen ongeschikt bevonden voor overige onderwijsrollen en er werd een 
oproep gedaan om EPAs te ontwikkelen voor het opleiden van en toevertrouwen van verantwoordelijkheden aan begeleiders van kleine groepen.

Om deze lacune in de literatuur op te vullen, werd met behulp van een cocreatie-methode een EPA-kader ontwikkeld voor de begeleiding van kleine groepen. In het tweede onderzoek dat in Hoofdstuk 3 werd besproken, werkten studenten en docenten samen aan het ontwerp van voornoemd kader en werden er drie workshops gegeven om de onderzoeksdoelen te bereiken. In de oriëntatieworkshop werden de participanten geïnstrueerd over de inhoud, onderzoeksopzet en wat er van hen werd verwacht. Vervolgens werd er een ontwerpworkshop gegeven waarbij studenten en docenten een lijst maakten van 11 EPAs en 17 competenties die zij vonden passen bij begeleiders van kleine groepen. Ten slotte werd er in de consensusworkshop overeenstemming bereikt over 9 taken en 12 competenties, die vervolgens in een overzicht werden geplaatst.

Aangezien het cocreëren van een EPA een nieuwe aanpak was, was het van belang om te onderzoeken hoe de deelnemende studenten en docenten hun ervaringen met cocreatie beleefd hadden, omdat een negatieve beleving de houdbaarheid van zowel de cocreatie-methode als het resulterende kader in het geding zou kunnen brengen. In het derde onderzoek dat in Hoofdstuk 4 wordt beschreven, hielden we daarom interviews met 11 studenten en 11 docenten die het kader uit Hoofdstuk 2 hadden gecocreëerd. De geïnterviewden gaven voornamelijk aan dat zij een positieve en productieve ervaring hadden met cocreatie. Studenten brachten regelmatig naar voren dat zij zich tijdens de cocreatie-oefening op hun gemak voelden vanwege de ondersteunende, vriendelijke, niet-confronterende en motiverende houding van de docenten uit hun groep. Ook docenten lieten weten dat zij zich prettig voelden bij de aanwezigheid van studenten vanwege de respectvolle en samenwerkende opstelling van studenten gedurende de activiteit. Er werden ook enkele negatieve ervaringen genoemd, zoals: overheersing door docenten, verlegenheid van studenten, geen grip op het onderzoeksonderwerp en een terughoudende deelname waardoor de actieve bijdrage door participanten werd beperkt. Het betrekken van zowel studenten als docenten bij het cocreëren van het kader werd als essentieel beschouwd, omdat dit belanghebbenden, docentprofessionaliseringsprogramma's alsook het cocreatie-proces meerdere voordelen biedt. Wat betreft de suggesties ter verbetering van student-docent partnerschappen waren het zorgvuldig selecteren van participanten en het geven van contextgebonden instructies voorafgaand aan de cocreatie-activiteit de aanbevelingen die het vaakst werden genoemd. Het onderzoek concludeerde dat het betrekken van relevante belanghebbenden bij het ontwerpproces diversiteit en zorgvuldigheid bevordert en dat daarom hun betrokkenheid als medeontwerpers in toekomstige onderwijsinitiatieven gewaarborgd moet worden.

Hoewel voor de ontwikkeling van het kader een gedegen ontwerpbenadering was gebruikt, waren deskundigen op het gebied van het gezondheidszorgonderwijs niet geraadpleegd en dit is belangrijk om controle en kwaliteit te waarborgen. In het vierde onderzoek dat in Hoofdstuk 5 wordt beschreven, hebben we daarom een gemodificeerde Delphi-methode gebruikt om het kader met behulp van internationale deskundigen te valideren. Eenendertig deskundigen op het gebied van het gezondheidszorgonderwijs namen deel aan drie online rondes. In Ronde 1 werd een 
gevalideerde rubric met 7 items gebruikt om de kwaliteit van de vooraf ontworpen negen EPAs te beoordelen, hetgeen resulteerde in behoud van drie EPAs, namelijk: het voorbereiden van een sessie met een kleine groep, het begeleiden van een sessie met een kleine groep en het reflecteren op zichzelf en de sessie. In Ronde 2 kozen participanten uit de pool van 12 competenties negen competenties die zij noodzakelijk achtten voor het uitvoeren van elke EPA waarover overeenstemming was bereikt. In Ronde 3 werd consensus bereikt over vijf, zes en vier subactiviteiten voor respectievelijk EPA 1, EPA 2 en EPA 3. Het definitieve kader werd ook voorzien van een gedetailleerde beschrijving van elke EPA, waaronder de context, een omschrijving, middelen voor het toevertrouwen van activiteiten en een schaal voor deze toevertrouwing.

Het gevalideerde EPA-kader beschrijft de inhoud en de eindtermen van de opleiding die docentprofessionaliseringsprogramma's zouden moeten nastreven. Het kader geeft echter geen details over hoe het onderwijsontwerp van een EPA-gericht docentprofessionaliseringsprogramma eruit moet zien. In het vijfde onderzoek dat in Hoofdstuk 6 wordt beschreven, stelden we een taakgericht onderwijsmodel voor door de EPA's aan te vullen met het vier-componenten instructieontwerp model, in het navolgende aangeduid met "4C/ID-model", de afkorting van het Engelse four-component instructional design model. Met dit model onderzochten we de mogelijkheid om het onderwijzen van een EPA op te delen in verschillende leertaken geordend naar mate van complexiteit, gevolgd door taakgericht opleiden waarbij eerst eenvoudige taken worden uitgevoerd in een gesimuleerde leeromgeving met een lage mate van natuurgetrouwheid (low-fidelity), alvorens complexe taken te verrichten in de échte leeromgeving op de werkplek. Vervolgens stelden we voor om deze opleiding te laten beginnen met eenvoudige leertaken in een low-fidelity leeromgeving en om de complexiteit van zowel de leertaken als de leeromgeving geleidelijk op te voeren naarmate meer competenties werden verworven. Daarbij zou gedurende het gehele opleidingscontinuüm langdurige supervisie geboden moeten worden om het wederzijds vertrouwen en de relatie tussen aios en supervisor te stimuleren en om tot een weloverwogen besluit tot toevertrouwen van activiteiten te komen.

In Hoofdstuk 7 worden de bevindingen van de onderzoeken, alsmede hun implicaties voor theorie en praktijk, globaal besproken. Daarnaast werden de sterke punten en beperkingen van het gehele onderzoeksproject besproken en werden er meerdere aanbevelingen gedaan voor toekomstige onderzoekers. Over het algemeen biedt dit onderzoeksproject een sluitend EPA-kader dat kan worden gebruikt voor het opleiden van docenten tot begeleiders van kleine groepen en voor het toevertrouwen van de daarbij behorende verantwoordelijkheden aan deze docenten. De betrokkenheid van alle drie de groepen belanghebbenden, d.w.z. studenten, docenten en onderwijsdeskundigen, bij het ontwikkelings- en validatieproces onderstreept de kracht van het verkregen kader. Het kader is bedoeld om op meerdere potentiële manieren van nut te zijn voor docenten in de vervolgopleiding, onderwijsontwikkelaars, onderwijsleiders en studenten. Voorts vult dit onderzoeksproject de literatuur over cocreatie aan door het domein van docentprofessionalisering eraan toe te voegen. We hebben geleerd dat het betrekken van studenten en docenten bij de cocreatie van een kader voor docentenopleidingen een essentiële en passende actuele 
onderwijsontwikkeling is. Het onderzoeksproject stelt verder voor om EPAs aan te vullen met 4C/ ID, waarbij EPAs de eindtermen van de opleiding beschrijven en 4C/ID vormgeeft aan het onderwijsontwerp van de opleiding. We verwachten dat dit proefschrift zou kunnen helpen de professionalisering van begeleiders van kleine groepen in het gezondheidszorgonderwijs te optimaliseren. 